Argonne

ANL-06/02

\title{
Site Environmental Report
}

for Calendar Year 2005

Environment, Safety, and Health/Quality Assurance Oversight Division

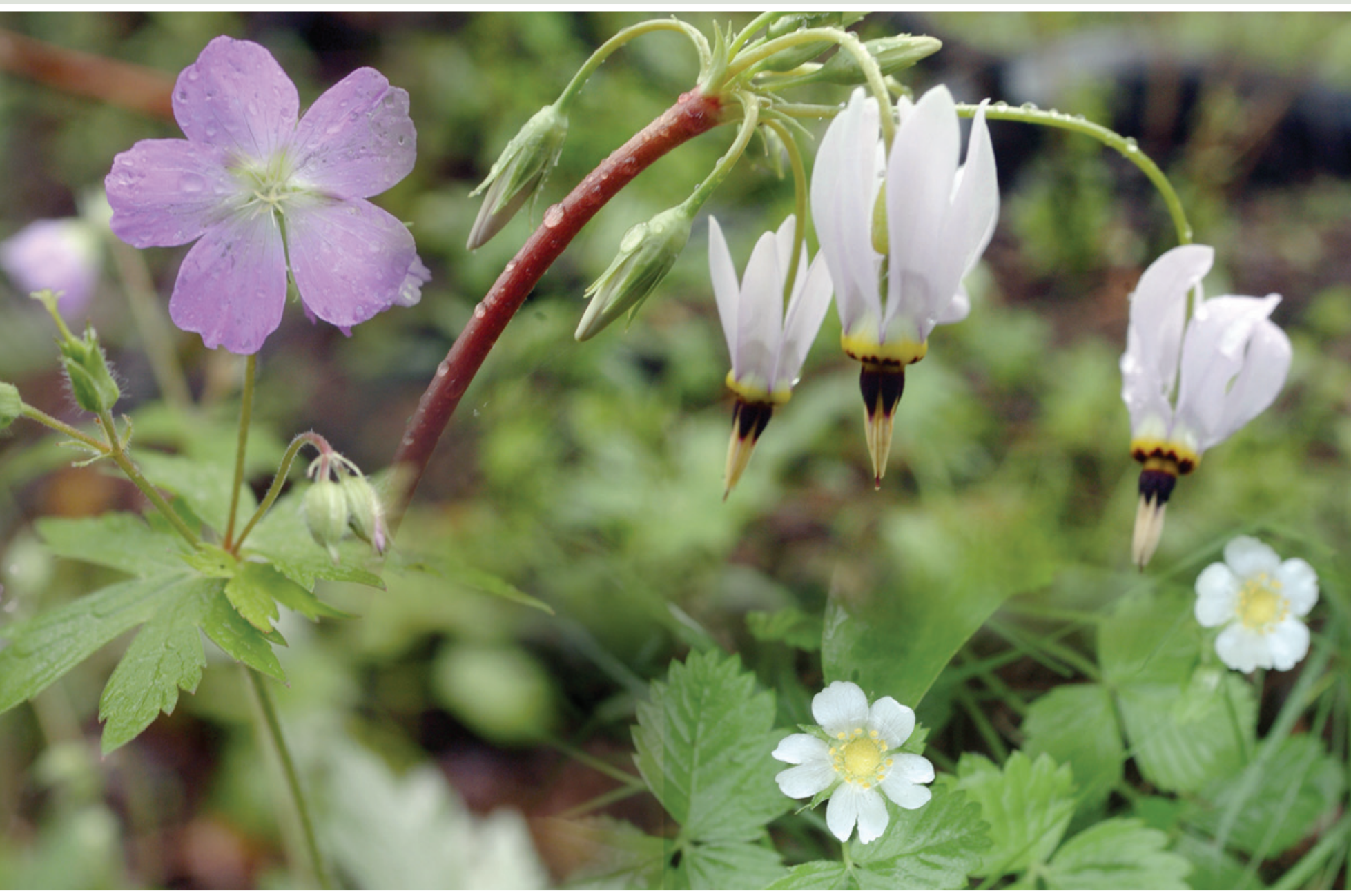




\section{About Argonne National Laboratory}

Argonne is a U.S. Department of Energy laboratory managed by The University of Chicago

under contract W-31-109-Eng-38. The Laboratory's main facility is outside Chicago, at

9700 South Cass Avenue, Argonne, Illinois 60439. For information about Argonne,

see www.anl.gov.

\section{Availability of This Report}

This report is available, at no cost, at http://www.osti.gov/bridge. It is also available

on paper to the U.S. Department of Energy and its contractors, for a processing fee, from:

U.S. Department of Energy

Office of Scientific and Technical Information

P.O. Box 62

Oak Ridge, TN 37831-0062

phone (865) 576-8401

fax (865) 576-5728

reports@adonis.osti.gov

\section{Disclaimer}

This report was prepared as an account of work sponsored by an agency of the United States Government. Neither the United States Government nor any agency thereof, nor The University of Chicago, nor any of their employees or officers, makes any warranty, express or implied, or assumes any legal liability or responsibility for the accuracy, completeness, or usefulness of any information, apparatus, product, or process disclosed, or represents that its use would not infringe privately owned rights. Reference herein to any specific commercial product, process, or service by trade name, trademark, manufacturer, or otherwise, does not necessarily constitute or imply its endorsement, recommendation, or favoring by the United States Government or any agency thereof. The views and opinions of document authors expressed herein do not necessarily state or reflect those of the United States Government or any agency thereof. 


\section{Site Environmental Report}

for Calendar Year 2005

by

N.W. Golchert and R.G. Kolzow

Environment, Safety, and Health/Quality Assurance Oversight Division, Argonne National Laboratory

September 2006

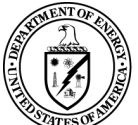




\section{Message from the Students}

\section{Victoria Canaday Howard and Mark Laskowski}

Biology II isn't just another boring class of science lectures. It's full of hands-on activities and realworld assignments like assisting Argonne National Laboratory with its involvement with its surrounding community.

The Biology II course at Downers Grove South High School allows students to research recent and emerging issues in the biological world around us and to develop our own answers to biological questions. Students have access to various scientific instruments and work on projects individually or in groups. The foundation for our ecological unit began with our trip to Treehaven and a visit to Argonne, where we looked at various ecological principles that apply to this project, the 2005 Argonne Summary Site Environmental Report. This project allows us to apply the ecological concepts that we have been learning throughout Biology II. It also allows us to work with Argonne scientists, giving us a rare chance to learn from them first-hand.

This outreach project also helps the class to meet and exceed Illinois science education standards. The first standard that must be met is to know and apply concepts that describe how living things interact with each other and with their environment. Along with that, we are required to know and apply concepts that describe the interactions among science, technology, and society. Through previous research experiments and applied experiences within our ecology unit, this project gave us the perfect opportunity to meet the state's goals.

As a class, when we started this project, we weren't really sure what we should expect. All we knew was

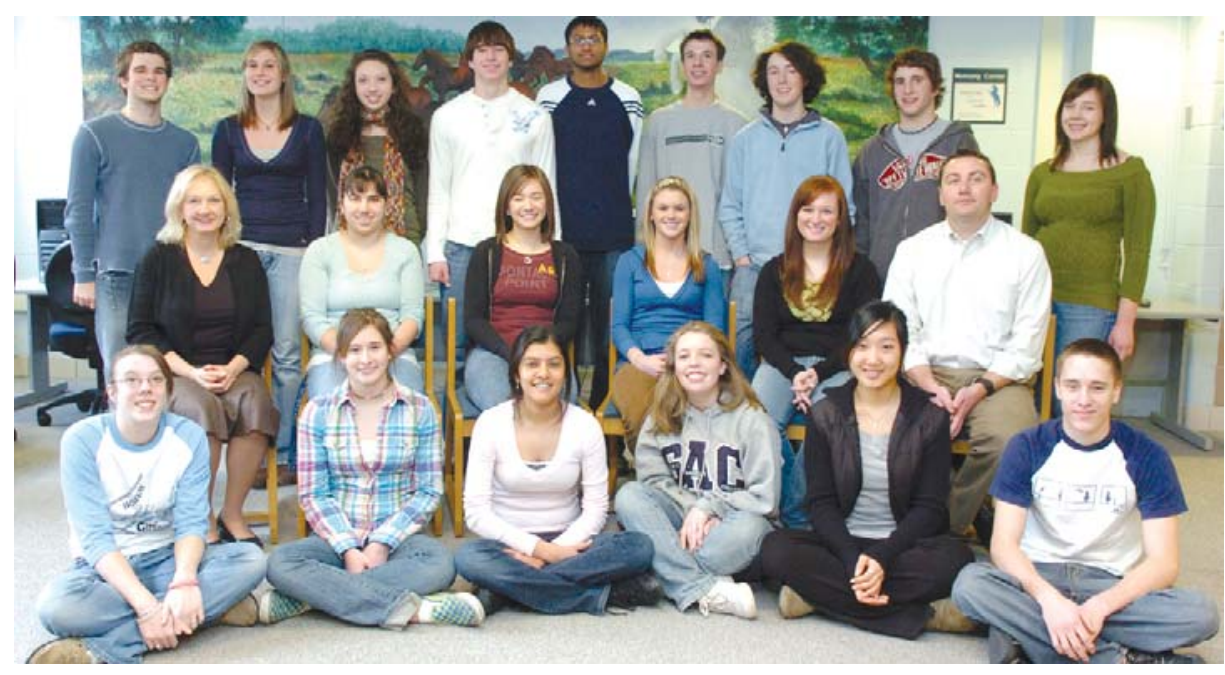

Biology II students at Downers Grove South High School: In the front row, from left to right, are Kayla Baader, Jenny Bauer, Sunita Rao, Siobhan Glenn, Danbee Paek and Mike Kasnick. In the middle row, left to right, are Mrs. Kathleen Luczynski, Jennifer Medon, Victoria Canaday Howard, Kelsey Wieties, Jennifer Krouwer and Mr. Scott Howard. In the back row, from left to right, are Cullen Deady, Ashley Brown, Julia Franzen, Mark Laskowski, Nikhil Hariharan, Kevin Agnew, Peter Mosiman, Ryan Bernardi and Christina Cavallo.

that it would be pretty awesome to say that we have published works for Argonne National Laboratory and that it would probably be more work than we were really ready for. It was a lot of reading and writing, and we can honestly say we learned quite a bit. We obviously acquired information that none of us knew before, but we also gained skills that will help us not only on future projects for this class, but in college and later in the workforce. This project has so many areas of learning; we couldn't have asked for a better experience.

Finally, it was a relief to find that not only did this project enhance our scientific knowledge, but we had a lot of fun doing it. Having this project as the conclusion of our ecology unit, we can honestly say that it allowed us freedom and creativity to explore our newly acquired knowledge.

This project would not have been possible without the help of a few very important people. We would first like to thank our teachers Mrs. Kathleen Luczynski and Mr. Scott Howard, who put up with us every day and guided us endlessly in finishing this book for Argonne. Whenever we had a question or concern, Mrs. Luczynski and Mr. Howard would be there to answer or address it. Every day they would push us one step closer to completing this massive project and helped us in any way possible. Both of them were so involved in this project that this book is as much theirs as it is ours. We would also like to thank Dr. Norbert W. Golchert and Mr. David Baurac from Argonne National Laboratory, who corrected and edited our writing to make sure that the information was accurate and complete.

Thank you Argonne National Laboratory for giving us the opportunity to be able to write this book, because it is such a good experience for students. 


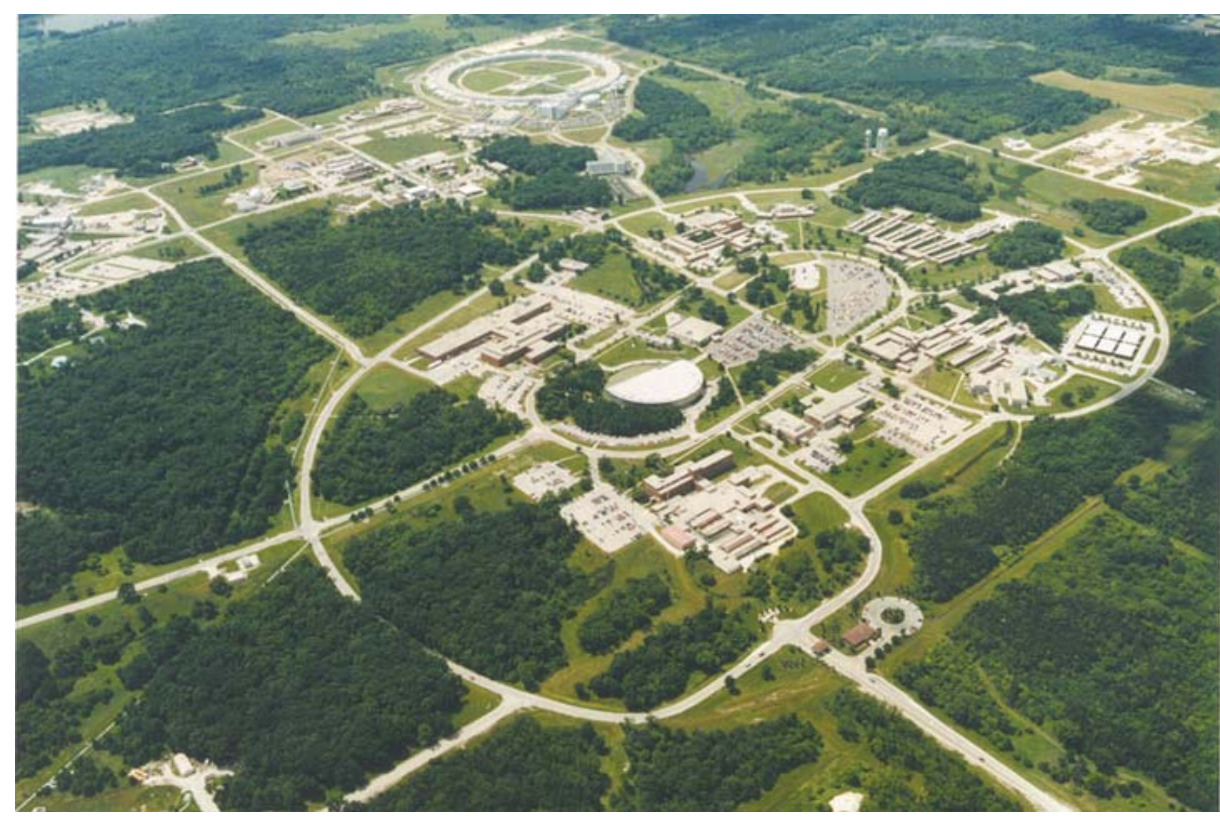

Aerial view of the Argonne site. Argonne is a federally funded research and development facility managed by UChicago Argonne, LLC for the U.S. Department of Energy's Office of Science.

\section{What Is Argonne?}

\section{Victoria Canaday Howard and Mark Laskowski}

Argonne National Laboratory's mission is to conduct research that helps solve nation-wide and worldwide scientific and technological problems. For example, Argonne researches and develops new materials and energy technologies, helps pharmaceutical companies develop medical cures for diseases, and addresses the issue of pollution by researching and developing technologies that help make vehicles more fuel efficient. Argonne also puts a large effort into educating future generations of scientists by offering educational programs and opportunities for students from pre-school through university level.

Argonne became the first national laboratory in the United States in 1946. Argonne is located on 1,500 acres of wooded land in the southeastern portion of DuPage County near Lemont. It is surrounded by Waterfall Glen Forest Preserve.
Argonne's campus has prairies, wetlands, deciduous forests, and coniferous forests. Sawmill Creek runs south across the Argonne site toward the Des Plaines River and eventually flows into it. Sawmill Creek serves many different purposes for Argonne, one of which is to serve as the main drainage system.

Argonne has a large and diverse employee population; 2,900 employees from 61 different countries around the world work at Argonne. Argonne conducts research in many fields, including chemistry, biology, medical research, physics, computer science, materials science, and many more. Every year about 50,000 people, including scientists, teachers, and students, visit Argonne.

Argonne is a federally funded research and development facility. Therefore, the United States government funds most operating costs at Argonne which, annually, adds to about \$475 million. Argonne is managed by UChicago Argonne, LLC for the U.S. Department of Energy's

\section{Table of contents}

- Message from the Students .. 2

- What is Argonne? 3

- Current Argonne

Research 4

- Radiation in General .......... 5

- Environmental Radiological

Program .................................. 6

- Hazardous Waste ............... 7

- Air Monitoring ................... 8

- Solid Waste Management ... 9

- Habitat and Wildlife

Management 10

- Science Education and the Community 11

For more information about Argonne's Site Environmental Report, contact Norbert Golchert at (630) 252-3912 or ngolchert@anl.gov. For more information about Argonne and its programs, visit the laboratory's World Wide Web site at www.anl.gov or contact Communications \& Public Affairs at (630) 252-5575.

Photos by George Joch. The text was edited by David Baurac. Design and layout by Dave Jacqué.

Office of Science.

Every year officials visit Argonne to ensure that the laboratory is doing its job properly and isn't harming the environment by, for example, releasing too much radioactive material into its surrounding environment. When environmental problems are found, Argonne must provide a plan to fix them. Then Argonne has to give regular reports about what has been successfully completed and what remains to be done. 


\section{Current Argonne Research}

\section{By Tina Cavallo and Siobhan Glenn}

Argonne National Laboratory is a place where scientists and engineers come together to open up new possibilities for the future. Argonne has brought us many important projects in the past. It was at Argonne that researchers confirmed that Beethoven suffered from lead poisoning, and it was through the amazing Access Grid, pioneered at Argonne,

that researchers in the
United States were able
to aid doctors on the
other side of the world
who were fighting the
SARS outbreak. Re-
searchers at Argonne are
currently researching and
developing new strategies
in areas as varied as
advanced nuclear reactors
and other energy sources,
medicine, and environmen-
tal science that will likely
prove to be just as signifi-
cant as Argonne's past
achievements.
Nuclear

designs and prototypes of most of the nuclear reactors producing energy around the world today were originally conceived and tested by Argonne. While it may seem intimidating to live near a nuclear research site, the community surrounding Argonne is in no danger. The laboratory's

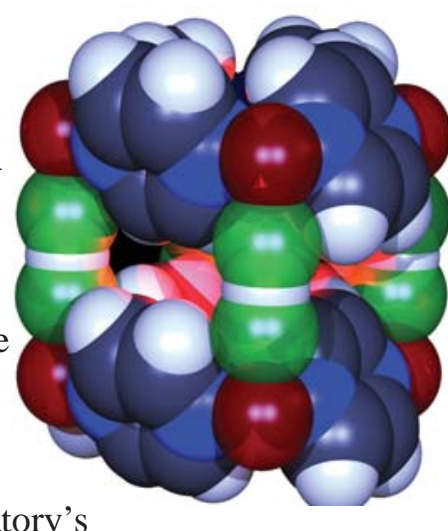
Argonne researchers have pioneered a new approach for making magnetic polymers, which may lead to new techniques for faster and more versatile computer chips

monitor blood sugar and inject insulin as needed Environmental Management Program provides Argonne's neighbors with quantitative risk data and has determined that the Argonne site is very safe.

\section{Energy Sources}

As a U.S. Department of Energy laboratory, Argonne has always been interested in finding new and more efficient energy sources. Current energy projects include fuel efficient cars, new batteries and fuel cells, and the conservation of U.S. oil and gas resources. The U.S. Department of Energy recently named Argonne the lead laboratory to test and evaluate new technologies for plug-in hybrid vehicles.

\section{Medicine}

Pharmaceutical companies use Argonne in their research, including a study discovering the structure of the HIV virus. Conducted at Argonne's Advanced Photon Source, this landmark research led Abbott Labs to develop Kaletra ${ }^{\circledR}$, a leading HIV/ AIDS treatment drug.

Argonne's recently opened Center for Nanoscale Materials will attract scientists from around the world to create and study materials that measure about onebillionth of a meter across. This research is expected to lead to new products in many fields; one medical example is nanoscale biosensors that directly into a diabetic patient's body.

\section{Environment}

One current environmental project is improving the population of native plants on Argonne's 1,500-acre campus. Scientists at Argonne believe that the re-introduction of native plants will reduce maintenance, improve erosion control, reduce air pollution, and increase biodiversity. Other environmental research goals met at Argonne include the conversion of six acres of vacant land to prairies. These, among many other accomplishments, have helped reduce the air emissions that Argonne is responsible for each year.

Research at Argonne promises great advances in many areas of science. The research in environmental, nuclear power, energy, and biomedicine provide new technologies and data to revolutionize

the world of

science.

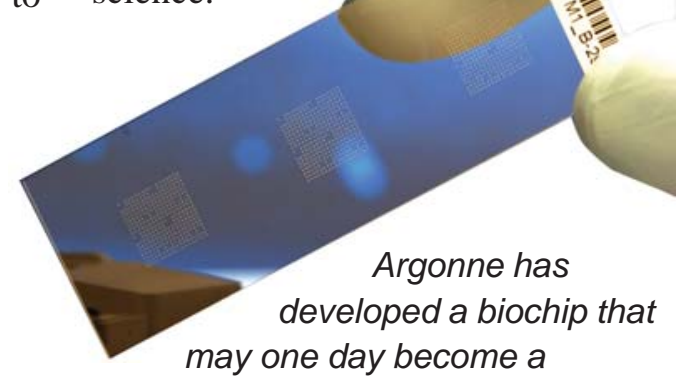
identifying human and veterinary infectious diseases. standard diagnostic tool for 


\section{Radiation in General}

\section{By Jenny Bauer}

All living things give off radiation, even you. Radiation in low doses is not harmful, since your cells are able to repair and replace themselves quickly. However, once you start getting radiation exposures greater than 1,000 mrem, the cells are not able to replace themselves fast enough, and they die or remain permanently changed. (A "mrem," or millirem, is one-thousandth of a "rem," which stands for "Roentgen Equivalent Man,” a unit that relates the dose of any radiation exposure to its biological effect.) This kind of high radiation exposure could cause problems fighting infection, lead to nausea, and make you weaker.

Radiation is energy in the form of waves or particles moving through space. The average annual radiation exposure received by any given person is about 360 mrem. About 300 mrem come from natural radiation, while the rest is from man-made radiation. Commonly, when radiation

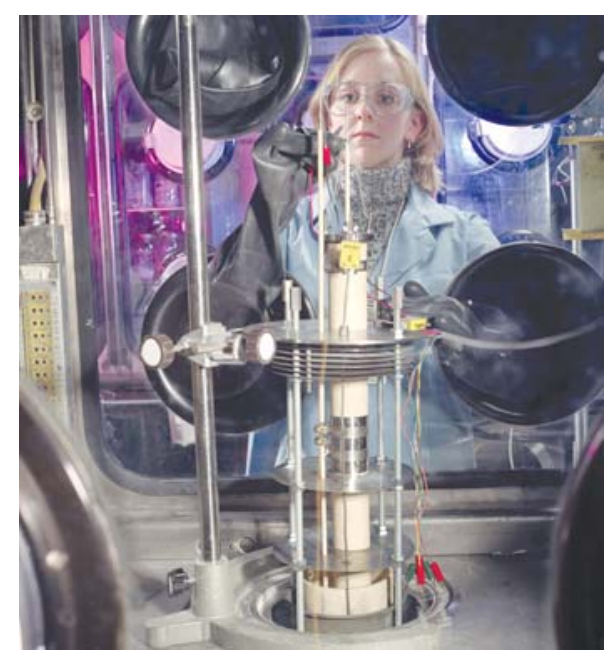

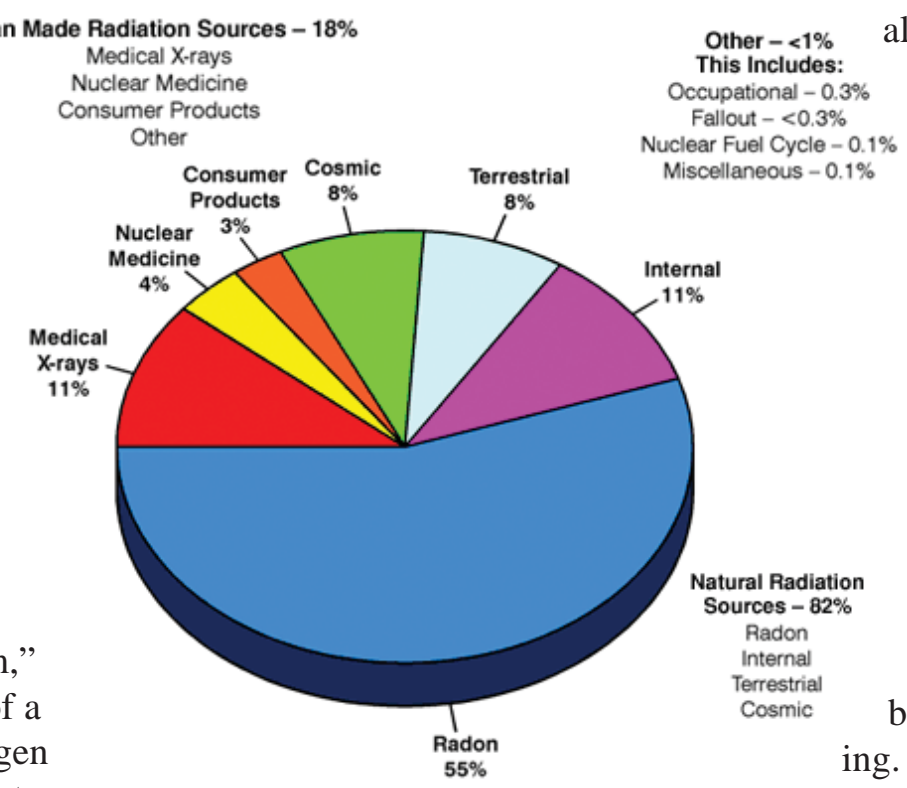

all examples of man-made radiation, in contrast to natural radiation. Natural, also known as background radiation, is the radiation you obtain from radionuclides in the ground and air and from cosmic sources.

\section{Radiation and the Public}

The short-term effects of exposure to large amounts of radiation are burns and radiation poisoning. Radiation poisoning can

This chart shows that about 82 percent of all radiation exposure to the public comes from natural sources, like radon in the soil and cosmic rays. Man-made sources account for the remaining 18 percent.

is discussed, what is being talked about is ionizing radiation. Ionizing radiation can damage matter, including living tissue.

When the topic of radiation is brought up, nuclear power plants or nuclear weapons come to mind. People generally do not think about radiation that comes from objects they use daily, including smoke detectors, televisions, cell phones, microwaves, and tobacco. These are

Argonne scientists and engineers who work with radioactive materials are careful to protect themselves and the public. Here, Argonne chemist Laurel Barnes prepares an experiment inside a glove box. cause premature aging or death. Possible long-term effects of radiation are cancer and mutations in your DNA. Children are more sensitive than adults to radiation because they are growing more rapidly and have more cells dividing, which gives radiation a greater opportunity to disrupt the growth process of the cells.

\section{Protection}

The three considerations of radiation protection are time, distance, and shielding. People do not realize that protecting themselves from radiation, such as solar radiation, is as easy as putting on sunscreen, wearing a hat, or avoiding direct exposure to the sun. When spending time near an object that gives off radiation, limit your time around the object. This will help limit the amount of radiation you are exposed to. The further away you are from a source of radiation the less radiation you will get. The EPA monitors the environment for abovenormal levels of natural radiation. 


\section{Argonne's Environmental Radiological Program}

\section{Jenny Krouwer and Kelsey Wieties}

Radiation at Argonne!? It's not what you think. The radiation emissions at Argonne are actually not harmful to people and are periodically monitored. Air, groundwater, and surface water at Argonne are potential sources of radionuclides and are under control.

The U.S. Department of Energy Order 450.1 requires that Argonne monitor the environment and conduct a surveillance program to determine any releases or movement of radioactive materials on the campus. Complying with these requirements is an important part of the Argonne sitewide monitoring program. All property containing radioactive waste at Argonne is disposed in a licensed and regulated low-level radioactive disposal site away from the campus.

\section{Measuring Radiation at Argonne}

Argonne uses different units to measure radiation, depending on what is being measured. To measure radiation emissions, the unit curie, or $\mathrm{Ci}$, is used. When measuring the biological risk of exposure, the unit rem is used. To measure radiation concentrations, Argonne uses pCi/L (pico-Curies per liter)for water, $\mathrm{fCi} / \mathrm{m}^{3}$ (femto-Curies per cubic meter) for air, and $\mathrm{pCi} / \mathrm{g}$ and fCi/g for bottom sediment. For measurements of penetrating radiation and population dose, units are reported in units of mrem/yr (millirem per year).

\section{Types of Radiation at Argonne}

The three major types of radiation found at Argonne are alpha, beta, and external penetrating gamma radiation. External penetrating

gamma radiation is found in radioactive waste storage facilities at Argonne. The levels of gamma radiation were measured using an aluminum oxide dosimeter at 17 onsite locations and five off-site locations. Other monitoring stations measure radioactive particles in the air. Alpha and beta activity that is naturally present in the air usually disappears within four days by a process called radioactive decay. In order to lower the dose rate, Argonne cleans up contaminated sites when it finds them.

The annual average radiation measurements for Argonne's on-site samples were similar to those of the off-site samples, which means that Argonne adds very little to the natural radiation already in its

\begin{tabular}{|c|c|c|}
\hline \multicolumn{3}{|c|}{$\begin{array}{c}\text { Summary of the Estimated Dose to a Hypothetical } \\
\text { Individual, } 2005(\mathrm{mrem} / \mathrm{yr})\end{array}$} \\
\hline Pathway & $\begin{array}{l}\text { Argonne } \\
\text { Estimate }\end{array}$ & Applicable Standard \\
\hline Air total & 0.036 & 10 (EPA) \\
\hline Water & 0.018 & $4(\text { EPA })^{a}$ \\
\hline Direct radiation & 0.001 & 25 (NRC) \\
\hline Maximum dose & 0.055 & $100(\mathrm{DOE})$ \\
\hline
\end{tabular}

a The 4-mrem/yr EPA value is not an applicable standard, since it applies to community water systems. It is used here for illustrative purposes.

environment. Much of the alpha, beta, and gamma-ray emitters in the air have been around for a long time. Incidents like Chernobyl have also contributed to an increased amount of radiation around the world.

Sawmill Creek, located at Argonne, flows into the Des Plaines River. Extensive measurements determined that the average alpha and beta particles in the river remained in the normal range. Therefore, radioactivity in the creek did not affect radioactivity in the river. One of the groundwater contaminants on Argonne's campus is hydrogen-3. The estimated annual

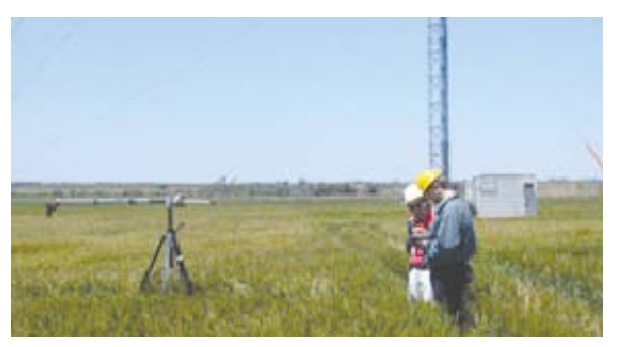

dose of hydrogen-3 to a maximally exposed individual living near Argonne was insignificant compared to the annual safe dose limit.

\section{Radiation Pathways and Doses}

Radiation doses found on and off campus were calculated to see how much the public was exposed to the radioactive materials originating from Argonne. These calculations were performed for three main exposure pathways: airborne, water, and direct radiation from external sources. The highest dose found in the air at the perimeter of Argonne's campus had a maximum value of $0.38 \mathrm{mrem} / \mathrm{yr}$, more than 250 times lower than the safe allowable limit. Most all of the doses are caused by air immersions of carbon-11. In addition, an evaluation was conducted to analyze doses to potential receivers of airborne radiation. This includes children at the Argonne Child Development Center and Darien School on $91^{\text {st }}$ Street. The estimated full-time dose at Darien School is about 0.01 $\mathrm{mrem} / \mathrm{yr}$. However, assuming that children are only present at the school for six hours and five days a week for 35 weeks a year, the actual dose they would be receiving is closer to 0.001 $\mathrm{mrem} / \mathrm{yr}$, which is 100,000 times lower than the safe allowable limit.

When it comes to water pathways, the most significant source is Sawmill Creek, which flows across the Argonne campus, through the Waterfall Glen Forest Preserve and empties into the Des Plaines River. 


\section{(Continued)}

It is important to note that Sawmill Creek is not used for drinking, swimming, or boating. Even so, the dose rates in Sawmill Creek water are all well below the safe standards for the general population. An external direct radiation pathway is found at the southern boundary of Argonne, located near the laboratory's waste storage facility. While no one lives in the forest preserve south of Argonne, people could be exposed to radiation from Argonne through activities like crosscountry skiing, horseback riding, or jogging. An individual who spent 10 minutes per week in that area would receive around $0.001 \mathrm{mrem} / \mathrm{yr}$, about 100,000 times lower than the safe allowable limit.
To put everything into perspective, after much monitoring, results reveal that the radioactive emissions from Argonne are very low and do not cause danger to the health or safety of the people living near the site.

Above all, the doses received from Argonne operations are insignificant compared to other sources of radiation.

\section{Hazardous Waste}

\section{Ryan Bernardi and Peter Mosiman}

Research and experiments produce things other than just facts and results. Sometimes they produce undesirable byproducts like hazardous waste. Argonne National Laboratory complies with all regulations that ensure Argonne's facilities treat, store, and dispose of hazardous wastes properly to protect the environment and human health. The regulations are defined in the Resource Conservation and Recovery Act. An important program at Argonne was the Argonne Environmental Remediation Program, which cleaned up hazardous materials from inactive waste sites on the Argonne campus.

Research activities at Argonne produce a lot of different waste chemicals. There are 24 hazardous waste management units on the campus: 16 container storage units, 1 storage tank, 4 treatment units, and 3 tank chemical treatment units. Argonne prepares annual reports to document that these management units effectively keep the local community safe from harm. Argonne is required to submit reports on how its hazardous wastes are treated. (See the table at right.)

A study that began in September 2005 successfully demonstrated a method to convert a mixed waste to a non-mixed waste that can be disposed of with fewer restrictions. Mixed waste contains both toxic and radioactive materials and is difficult to dispose of under present environmental law. The September experiment exposed a mixture containing lithium, a hazardous chemical, and low levels of radionuclides to water. The lithium reacted with the water to produce a non-hazardous chemical product that can be washed out of the mixture, leaving a low-level radioactive waste that can be disposed of.

Argonne also produces large amounts of sewage sludge and other special non-hazardous wastes, as defined by the Illinois Environmental Protection Agency (IEPA). Argonne disposes of all non-hazardous waste in regulated off-site landfills. The IEPA requires that Argonne file a report on waste management activities every year by Feb. 1 .

Argonne comes up with an inventory of the wastes it produces, and works through it. If these volatile wastes were to be accidentally released, the resulting air and water contamination could harm the community. This is the main reason Argonne takes pride in properly handling and disposing of the hazardous wastes it produces. In addition to genuinely caring about the well-being of the people in the surrounding towns and cities, Argonne is considerate of the environment and the surrounding communities.

\begin{tabular}{|c|c|c|}
\hline $\begin{array}{l}\text { Waste generated and } \\
\text { disposed of or recycled }\end{array}$ & Volume (gal) $^{\mathrm{a}}$ & Weight (lbs) \\
\hline Aerosol cans & 85 & 228 \\
\hline Brake cleaner fluid ${ }^{\mathrm{b}}$ & 8 & 67 \\
\hline Coal combustion samples & 250 & 500 \\
\hline Compressed gases & 21 & 33 \\
\hline Cutting oils with lead and solvents & 110 & 1,016 \\
\hline Diesel fuel contaminated debris & 30 & 120 \\
\hline Electropolishing solutions & 425 & 3300 \\
\hline Lead-contaminated debris & 745 & 3,725 \\
\hline Oil-based paint & 30 & 332 \\
\hline Used oil - hazardous & 165 & 1,035 \\
\hline Mercury-containing lamps ${ }^{\mathrm{b}}$ & 7,800 & 7,800 \\
\hline Lead-acid batteries $^{\mathrm{b}}$ & 750 & 7,500 \\
\hline
\end{tabular}




\section{Air Monitoring}

\section{By Ashley Brown \\ and Julia Franzen}

Inhale....exhale. Do you know what's in the air you're breathing? Argonne monitors the air on its campus in order to comply with laws that have been created for the benefit and well-being of the public and the environment. Air monitoring is performed at Argonne to ensure compliance with the laws established by local and national environmental agencies.

\section{Air monitoring}

Argonne, in general, is in compliance with the laws that apply to it. Argonne's air monitoring program determines if the projects and operations carried out at Argonne are done in compliance with the laws set for the environment and the laws set to run an experimental laboratory. Air monitoring must be done continually to compare air quality over time and to learn if air quality is increasing or decreasing and why.

It is necessary to determine both the positive and negative effects Argonne has on its surrounding environment and the community. Argonne's experiments and operations are done to further understanding, awareness and to improve people's lives. At what cost do these developments come? Air monitoring is done to ensure that Argonne's activities do not harm people or the environment.

\section{Environmental Protection Agency}

Argonne, as with any organization that has an environmental compliance program, must meet Environmental Protection Agency requirements on air quality. The National Ambient Air Quality

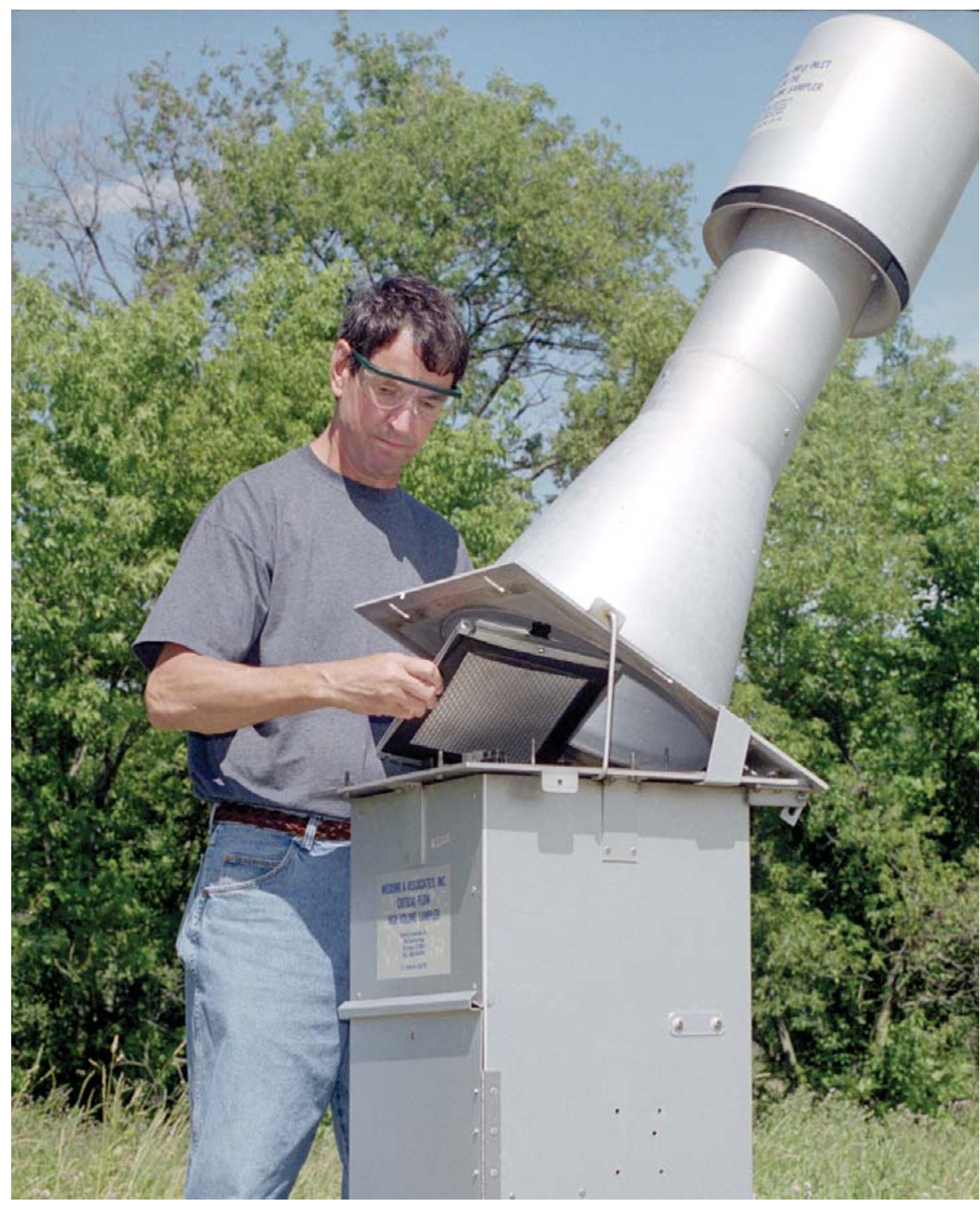

Standards (NAAQS) are EPA healthbased standards for carbon monoxide, nitrogen dioxide, lead, ozone, particulate matter and sulfur dioxide.

Argonne operations that result in air emissions must be evaluated to determine their effect on the NAAQS in the Chicago area, to ensure they do not deteriorate the existing air quality.

In the case of ozone and particulate matter for which the Chicago area is designated non-attainment with the standards, emissions must be evaluated to ensure that they do not prevent the area from achieving attainment according to state planning. Lack of obtaining proper permits can result in fines and ultimately halt the offending activities.

\section{Clean Air Act}

The Clean Air Act is a federal law that sets limits for air pollutants and emissions, as well as operating criteria for pollutants. Argonne's Site Implementation Plan commits the laboratory to meet standards for safe and clean air. Each year, Argonne obtains a permit from the Illinois Environmental Protection Agency that allows open burning. Argonne is considered a major source of air pollution because of the emissions given off by its boiler house, which provides heat for most of the office and laboratory buildings on the Argonne campus. Argonne tracks boiler-house emissions for 


\section{(Continued)}

opacity and sulfur dioxide. Argonne must pay annual fees based on the amount of pollutants it emits into the environment. Carbon monoxide emissions are regulated but are not part of the fee.

\section{NESHAP}

Argonne's Title V permit refers to requirements set by the Clean Air Act. Argonne applied for this permit, which includes standards regarding asbestos. In compliance with Title V, National Emission Standards for Hazardous Air Pollutants (NESHAP) and the Occupational Safety and Health Administration, Argonne removes asbestos on its campus with specially trained crews or contractors. In October 2005, one violation of proper asbestos disposal occurred when a roofing contractor cut into pipe covering that had asbestos. This released the asbestos into the air and violated regulations that require asbestos-removal activities to be fully enclosed.

In addition to emitting small amounts of radionuclides and asbestos, Argonne has sources of conventional air pollutants like the steam plant, the ethanol/gasoline fuel dispensing facility, two alkali metal reaction booths, two dust collection systems, an engine test facility, diesel generators, and pollutants from fire training activities. Currently all of these sources are operated in compliance with federal and state regulations. Another area of concern is the gas monitoring of landfills at Ar-

\section{Solid Waste Management}

\section{Danbee Peak and Sunita Rao}

Did you know?

According to EcoFuture ${ }^{\mathrm{TM}}$, the waste generated each year in the United States would fill a convoy of 10-ton garbage trucks 145,000 miles long, more than halfway to the moon. So what is being done to reduce waste? Argonne has a solid waste management system that not only disposes of waste properly, but also prevents pollution and minimizes the amount of waste generated.

\section{Terms to keep in mind}

Non-radiological waste: Waste that doesn't include radiological chemicals

Solid waste: Waste that is not liquid or radiological; for example, plastic, paper, sewage, sludge, etc.

RCRA: Resource Conservation and Recovery Act.

EMS: Environmental Management System.
ISMS: Integrated Safety Management System.

DOE: Department of Energy

IEPA: Illinois Environmental

Protection Agency

Argonne P2 program: Argonne

Pollution Prevention Program

\section{Guidelines Argonne follows}

1. Argonne implements a sitewide Pollution Prevention/ Waste Minimization (P2/WM) program in accordance with DOE Order 450.1 and site-specific performance measures.

2. The P2 program tracks the generation of waste and recyclable material at Argonne and monitors Argonne's progress with regard to the program's annual performance measures and goals.

3. The IEPA requires Argonne to submit an annual non-hazardous special waste report by February 1 of the following year. This report describes the activities of the gonne. These landfills, which have been closed for years, produce methane, but monitoring shows that their methane emissions are very low and are not spreading, which is a good thing!

NESHAP contains specific guidelines for asbestos and radionuclides. Radionuclides are naturally occurring, but they can also be artificially produced and in excess can create dangers to the environment. Radionuclides at Argonne are produced by a variety of sources, including hot cell facilities, radioactive materials, and particle accelerators. While Argonne has a fair number of emission points, the laboratory's actual radionuclide emissions are very small, compared to NESHAP standards. previous year.

4. Argonne must comply with the RCRA regulations.

How does Argonne dispose of solid waste?

Argonne generates a large volume and variety of non-hazardous wastes. Until 1992, Argonne disposed of its solid waste at a landfill located in the northwest corner of the campus. Since 1992, all non-hazardous waste is disposed of at permitted waste landfills off campus.

\section{Summary}

As you can see, solid waste management is an important job. Argonne has to keep track and monitor all waste that is being generated on campus. While managing all the solid waste, Argonne also has to make sure that their programs are in compliance with all regulations. Managing solid waste properly helps the environment to stay clean and healthy. 


\section{Habitat and Wildlife Management}

\section{By Cullen Deady}

and Mike Kasnick

Imagine if...

You are an organism inhabiting a backyard full of biologically diverse species. It doesn't matter whether you are big or small, blue or green, plant or animal. The question you must ask is how the backyard's owner manages you, along with the other organisms around you. Then imagine that you are in a space about 2,000 times larger than a backyard. How is this management done?

Argonne National Laboratory spends a large amount of time and effort monitoring, managing, and improving the wildlife and habitats on its campus. To fully grasp this concept, we must look at Argonne itself, what specific tasks must be done, why it is monitored, and any endangered species that inhabit Argonne and the surrounding area.

\section{Land distribution}

Argonne occupies a 1,500-acre campus where dozens of science and office buildings share space with eight acres of prairie, 45 acres of wetland, and 700 undeveloped, mostly forested acres. The prairie is mostly grassland, which includes

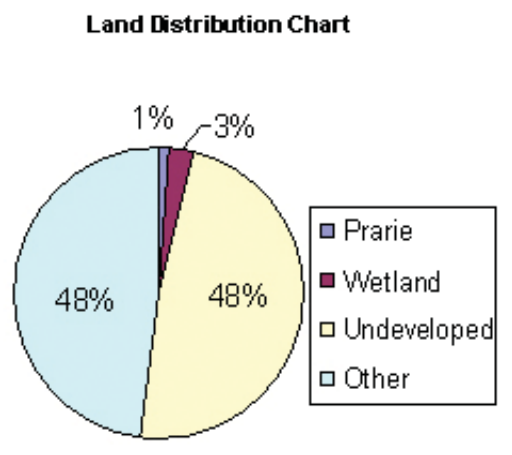

grasses such as Big Blue Stem and Indian grass. The wetlands have a primarily water-based community of organisms, the main organism being cattails. Savannah separates the woodland from the prairie; in the savannah there are scattered trees, along with prairie grasses. The common trees in the woodlands and the savannah area are red maple and sugar maple. Adjacent to Argonne,

plants that have difficulty re-growing and maintaining a steady population are replanted. Controlled burning and replanting are done periodically to ensure that the native species remain at Argonne and do not die out.

Another thing that Argonne does to maintain a healthy environment is to remove radioactive waste, along with any other wastes present. By removing these wastes, organisms are surrounded by more nourishing abiotic factors, such as rich soil and water, allowing them to continue to grow. Also, Argonne uses a technology known as phytoremediation, which uses plants to clean toxic chemicals from groundwater.

Argonne is committed to the long-term environ-

and surrounding it, is the Waterfall Glen Forest Preserve.

\section{Monitoring}

In order to keep the Argonne site flourishing, many actions are taken. For instance, controlled burns are used to restore native vegetation. They wipe out all invader species that are not adapted to recovering from the burns, leaving only the native ones to re-grow. Those native mental stewardship of its campus. To support this commitment, Argonne follows the guidance of the U.S. Department of Agriculture and all regulations from this organization. Argonne uses an Environmental Management System to make sure all environmental issues are systematically identified, controlled, and monitored.

Argonne's Environmental Safety and Health policy states that all

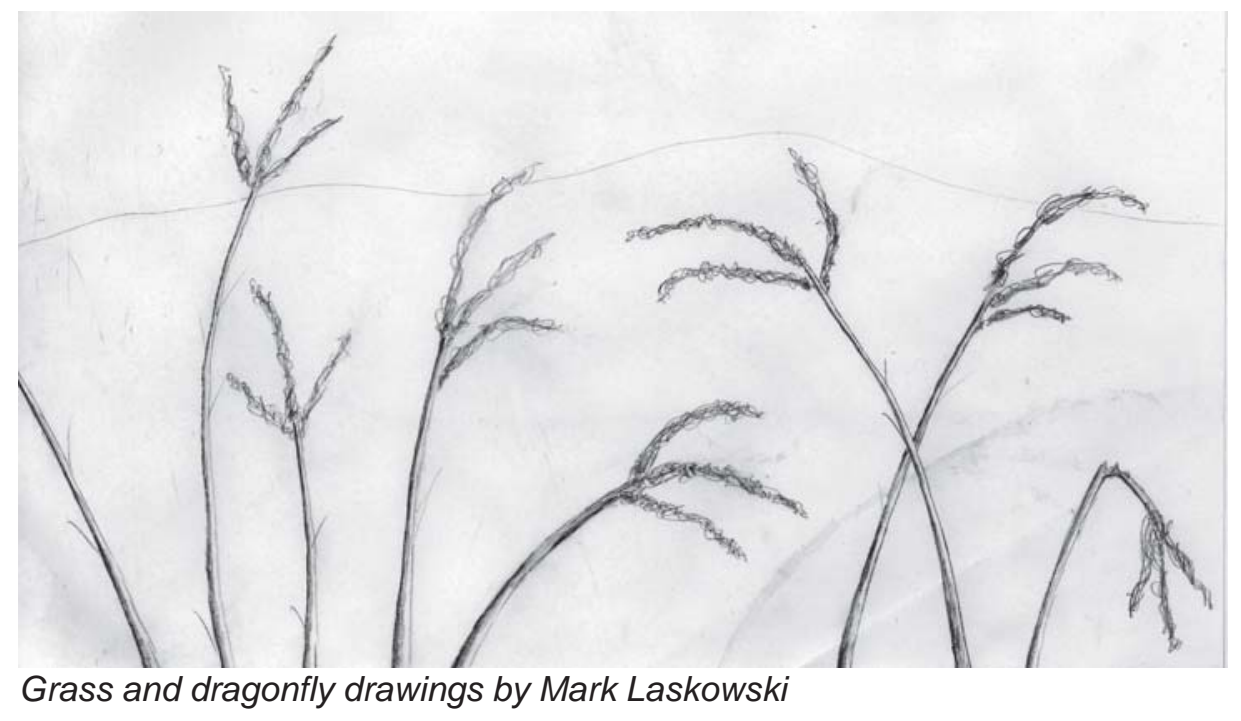




\section{(Continued)}

experiments, research, and tests must be done in a safe and environmentally sound manner.

\section{Endangered species}

Endangered species are federally protected by the Endangered Species Act (ESA) of 1973. There are no known endangered species that reside on the Argonne campus, but some may inhabit the Waterfall Glen Forest Preserve that surrounds Argonne.
Endangered species protected at Waterfall Glen include Hines Emerald Dragonfly, Leafy Prairie Clover, Indiana Bat, and Lakeside Daisy. Some endangered species that occasionally visit the Argonne site include the Bald Eagle, Piping Plover, and Least Tern. They have only been known to show up in winter and do not breed or nest at Argonne. These animals are closely monitored.

Argonne is in compliance with the ESA and has had no previous violations of the act.

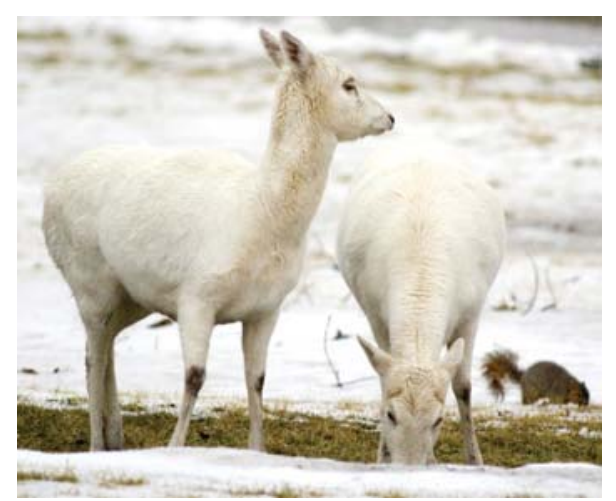

The "white deer" at Argonne are fallow deer native to Europe and parts of Asia. They are descended from a herd kept by a previous owner of the site.

\section{Science Education and the Community}

\section{By Jennifer Medon}

and Kayla Baader

\section{Ask a Scientist}

Argonne's “Ask a Scientist” program was established in 1991 to assist K-12 students and teachers with science questions. Any one can log on to the Web site at newton.dep.anl.gov/aasquesv.htm, ask a science question, and receive an answer from a volunteer corps of international experts. Since it was created, the scientists have answered more than 20,000 questions. The site now receives about eight million visits a year.

\section{Interactions with local schools}

Argonne offers many educational programs for Chicago-area K-12 schools. These programs include a number of hands-on science activities that show students how much fun science can be.

Argonne also works with Downers Grove South High School students to condense a large, highly scientific environmental annual report into this smaller and easier-to- read summary of the laboratory's programs that protect the environment on and around the Argonne campus.

\section{Rube Goldberg contest}

One of the best known contests that Argonne annually holds is the Rube Goldberg contest, named after the Pulitzer Prize-winning cartoonist, who drew ridiculously complicated inventions for accomplishing simple, everyday tasks. Students are challenged to bring these inventions to life, to create machines and inventions of much complexity that use ordinary objects to perform very simple and everyday tasks, like peeling an apple or sharpening a pencil, as extravagantly as possible.

\section{Women in Science}

The Women in Science program was founded by the Argonne National Laboratory Director in June of 1990. Its purpose is to recruit, retain, and promote women to diversify and strengthen the scientific workforce. There is also the Introduce a Girl to Engineering Day and the Science Careers in Search of Women confer- ence, both held annually, to encourage girls to pursue engineering and scientific careers.

\section{Open house}

Argonne holds public open houses about once every three years. These events offer demonstrations, exhibits, tours, and presentations about environment, energy, safety, chemistry, computing, biology, physics, materials science, X-ray science, transportation, engineering, and nuclear power. In addition to the open house, tours of Argonne are held by reservation only; all visitors must be at least 16 years old, unless they are accompanied by an adult.

\section{Web site}

Argonne has much to offer online. Argonne's Web site at www.anl.gov has services with information about everything one would need to know about Argonne, as well as a weather forecast for anywhere in the world. For younger people, there is a small section with games to help with math skills and for students to interact with other students and scientists. 


\section{Argonne}

\section{Environment, Safety, and Health/Quality Assurance Oversight Division}

Argonne National Laboratory

9700 South Cass Avenue, Bldg. 201

Argonne, IL 60439-4832

www.anl.gov
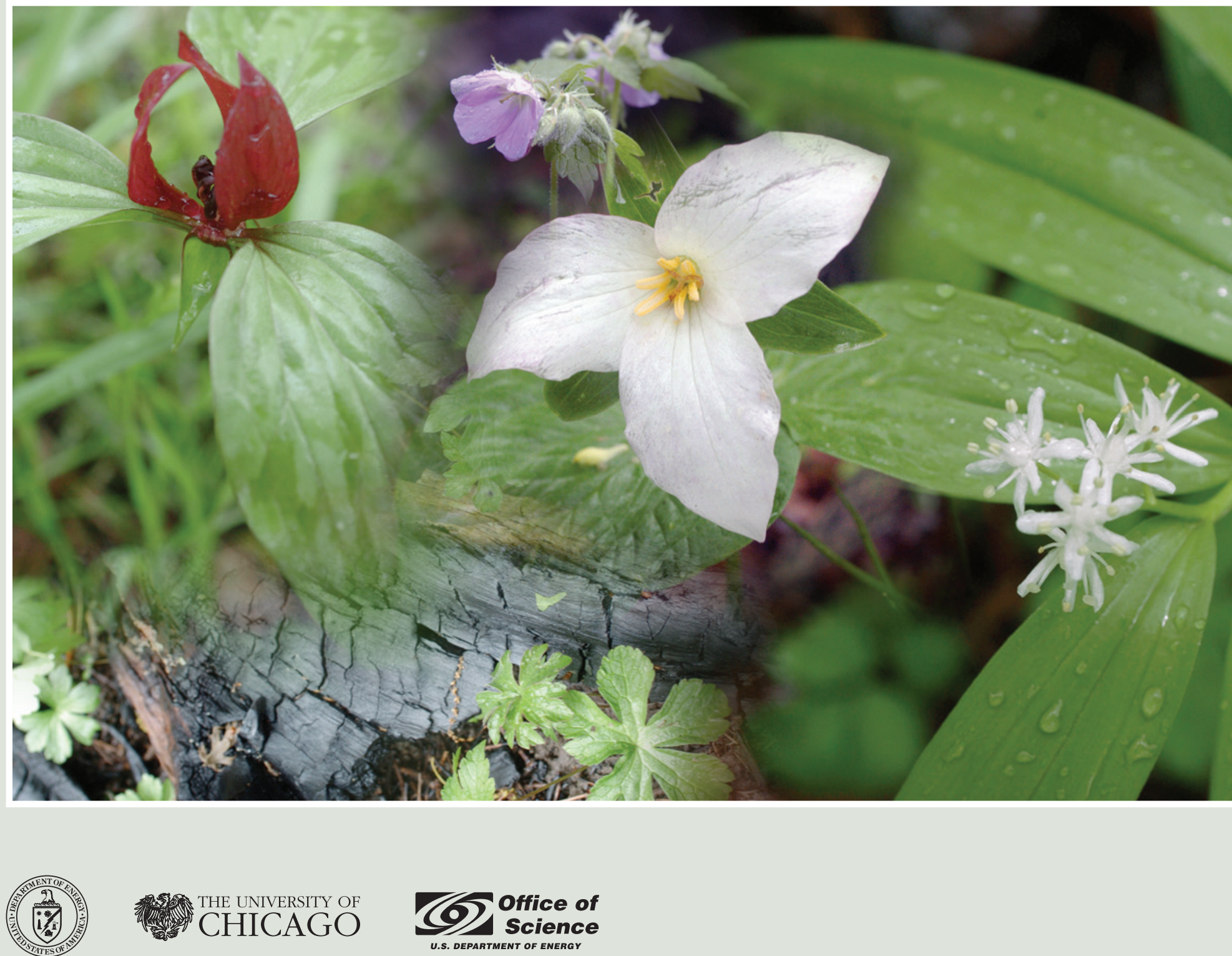